\title{
Diversity and Relative Abundance of Solitary Bees on Jatropha Curcas Crop in Sirmour and Solan Hills of Himachal Pradesh, India
}

\author{
Vinod K. Mattu' ${ }^{1}$ Arun Kumar ${ }^{2}$ \\ Sociobiology and Behavioural Ecology Research Lab, Deptt. of Biosciences, Himachal Pradesh University, Shimla (H.P.)-171005. India
}

\begin{abstract}
Studies on diversity and relative abundance of solitary bee visitors to Jatropha curcas crop was made by collecting the flower visitors in different sites located at Nahan $(933 \mathrm{~m})$ of Sirmour hills and Arki (1104 m) of Solan hills of Himachal Pradesh, during the years from 2012-2016. Insect diversity studies showed that Jatropha flowers were visited by 16 species of bees belonging to 4 families of order Hymenoptera of class Insecta. Of these, 7 species belonged to Apidae, 5 to Halictidae, 3 to Megachilidae and 1 to Andrenidae family. Analyses of data on relative abundance of different solitory bee visitors revealed that Xylocopa fenestrata was the most abundant bee visitor to Jatropha flowers in the two experimental sites i.e. Nahan (25.85\%) and Arki (24.84\%). Other important bees pollinators at Nahan and Arki were Ceratina gigantica (21.44\% and 21.04\%), Megachile flaviceps (9.81\% and 9.41\%), Halictus sp. (9.61\%,and 9.21\%) and Andrena sp. (3.20\% and 5.21\%).
\end{abstract}

Keywords: Solitary bees, Relative abundance, Jatropha curcas, Sirmour and Solan Hills

\section{Introduction}

The Himalaya is a store house of large array of diversity in food, fodder, vegetables and medicinal plants which are grown in valleys, hilly terraces and exposed flat mountain tops. One of the richest sources of biological diversity in the world, the Indian Himalayan region, is having a wide range of medicinal and aromatic plants. Of 17,500 flowering plants known to occur in India, about 3000 are recognized for medicinal uses (Sharma and Mudgal, 1997). Jatropha curcas (Euphorbiaceae) is a widely cultivated crop in Africa, Central and South America, India and Southeast Asia (Katembo and Gray, 2007; Maes et al., 2009). Jatropha is one of the crops cultivated in Himachal Pradesh for its medicinal and environmental importance. However, there are inadequate information on the bee pollinator status in terms of diversity and relative abundance on Jatropha in Himachal Pradesh despite the awareness of its environmental and economic importance. Pollination is essential stage in the reproduction of flowering plants and involves the transfer of pollen grains from male to female part of flower with the help of abiotic and biotic pollen dispersal agents. Wind, water and gravity are the important abiotic agents, whereas, insects, birds, bats and small mammals are the primary biotic agents (Free, 1993). Various insect groups which are of prime significance in pollination of agricultural and horticultural crops are Hymenoptera, Diptera, Lepidoptera, Coleoptera and Thysanoptera (Michener, 1974). Of these, Hymenopterans are the most important insect pollinators because of their high energy requirements and tendency for collecting food for their brood in the form of pollen and nectar. Pollinators are extremely diverse, with more than 16,000 pollinator bee species have been described worldwide (Michener, 2000; Kevan, 2003). Insect pollination mostly bees is necessary for the pollination of $75 \%$ of all crops that are used directly for human food worldwide (Khan and Khan, 2004). Many investigators have studied the diversity and relative abundance of different agricultural crops in relation to nonApis solitary bees pollination in Europe, North America,
South America and Australia (McGregor, 1976; Goodman and Fisher, 1991; Gary, 1992; Free, 1993; Morse and Calderone, 2000). But, only a few studies have been conducted regarding the role of solitary bees in pollinating various mountain crops (Mishra et al., 1976; Mattu, 2008, 2010). Therefore, present investigation was conducted on the diversity and relative abundance of different bee species visiting Jatropha crop in Sirmour and Solan hills of Himachal Pradesh.

\section{Material and Methods}

Solitary bees pollination studies have been conducted on Jatropha curcas crop located at Nahan (latitude $30^{\circ} 33^{\prime} \mathrm{N}$, longitude $77^{\circ} 17^{\prime} \mathrm{E}$ and altitude $933 \mathrm{~m}$ ) in Sirmour hills and Arki (latitude $31^{\circ} 09^{\prime} \mathrm{N}$, longitude $76^{\circ} 57^{\prime} \mathrm{E}$ and altitude $1104 \mathrm{~m}$ ) in Solan hills of Himachal Pradesh, during the months of July and August of the years 2012-2016, when these crop were in full bloom. Studies on diversity and relative abundance of various bee visitors to Jatropha flowers have been made by selecting trees at random, on the basis of their size, flowering state and number of branches. The experimental branches selected had nearly same size with respect to their spread, phase of flowering and height above the ground. The observations were started 2 to 3 days after the flowering commenced and continued under good climatic conditions till petal fall. Relative abundance, of different bee visitors was determined in terms of their visits per 500 flowers/10 minutes (Verma and Chauhan, 1985). The observations were recorded from 0800 to 1700 hours of a day and average counts at these hours gave abundance of a bee pollinator for that particular day. All bee visitors on Jatropha flowers were collected, killed and identified. Identification of different insect specimens was done with the help of standard keys.

\section{Results and Discussion}

Solitary bee diversity studies showed that Jatropha flowers were visited by 16 species of bees belonging to 4 families of 


\section{International Journal of Science and Research (IJSR) \\ ISSN (Online): 2319-7064 \\ Index Copernicus Value (2013): 6.14 | Impact Factor (2015): 6.391}

order Hymenoptera of class Insecta. Of these, 7 species belonged to Apidae, 5 to Halictidae, 3 to Megachilidae, and 1 to Andrenidae family. These results corroborate the earlier findings of pollinators were selective in their floral visits and are shown to choose flowers which best meet their energetic requirements (Abrol, 1989). Burkill (1909) started that Xylocopa spp. was the most important flower visiting insects in India more active than Apis florea on many cultivated crops. Popov (1936), Mavromoustakis (1938, 1951), Michener (1966, 1994), Peters (1972) and Gupta (1987, 2003a) have described several species of wild solitary bees from different areas of this country. Apidae were represented by species like Xylocopa fenestrata, Trigona iridipenis, Ceratina gigantica, Ceratina sp., Anthophora sp., Amegilla sp. and Thyreus sp.etc. Of the family Halictidae, species like Halictus himalayensis, Halictus simlaenis, Halictus sp., Nomia himalayana and Nomia elliotii etc. Family Megachilidae was represented by Megachile flaviceps, Megachile lanata and Megachile sp. In addition, a single species of Andrena belonging to family Andrenidae was also recorded as pollinator of Jatropha crop in Himachal Pradesh (Table 1). Analyses of data on relative abundance of different bee visitors revealed that Xylocopa fenestrata was the most abundant bee visitor to Jatropha flowers in the two experimental sites i.e. Nahan (12.9 \pm 2.3 , $25.85 \%)$ and Arki $(12.4 \pm 2.2,24.84 \%)$. Other important solitary bee pollinators at Nahan and Arki were Ceratina gigantica $(10.7 \pm 1.5,21.44 \%$ and $10.5 \pm 1.6,21.04 \%)$, Trigona iridipenis $(3.8 \pm 0.9,7.61 \%$ and $3.5 \pm 0.8$, $7.01 \%)$, Anthophora sp. $(2.6 \pm 0.7,5.21 \%$ and $2.7 \pm 0.4$, $5.41 \%)$, Amegilla sp.( 2.4 $\pm 0.4,4.80 \%$ and $2.5 \pm 0.6$, $5.01 \%)$, Megachile flaviceps $(4.9 \pm 1.5,9.81 \%$ and $4.7 \pm 0.5$, $9.41 \%)$, Halictus himalayensis $(4.8 \pm 0.8,9.61 \%$ and

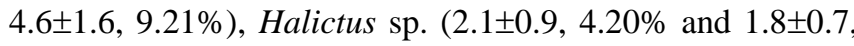
$3.60 \%)$, Nomia elliotii $(3.4 \pm 0.5,6.81 \%$ and $3.8 \pm 0.5,7.61 \%)$, Megachile sp. $(0.7 \pm 0.3,1.40 \%$ and $0.8 \pm 0.3,1.60 \%)$ and Andrena sp. $(1.6 \pm 0.4, \quad 3.20 \%$ and $2.6 \pm 0.7,5.21 \%)$ respectively (Table 2-3, figure 1-2). Therefore, present results suggest that family Apidae and Halictidae were the most abundant bee pollinators of Jatropha at Nahan $(64.92 \%, 20.64 \%)$ and Arki $(63.32 \%, 20.44 \%)$ site (Tables 2-3). The higher population of Xylocopa fenestrata in experimental sites may be due to its being native species and thus having better adaptability to local environmental conditions. These results are in conformity with the earlier observations of bees in India have been reviewed by Atwal (1970), Batra (1977) and Kapil (1986). Recently, Raju and Ezradanam, 2002; Muthuraman and Saravanan, 2004; Ashoke et al., 2005 reported that Xylocopa spp., Ceratina sp., Anthophora sp., stingless bee, Trigona iridipennis (Apidae); Halictus sp. (Halictidae) and Megachile sp. (Megachilidae) as the prominent bee visitors to this crop.

Table 1: Solitary bee species visiting Jatropha curcas flowers wih their taxonomic status

\begin{tabular}{|l|l|l|l|}
\hline Family: Apidae & Family: Halictidae & Family: Megachilidae & Family: Andrenidae \\
1. Xylocopa fenestrata & 8. Halictus himalayensis & 13. Megachile flaviceps & 16. Andrena sp. \\
2. Trigona iridipenis & 9. Halictus simlaenis & 14. Megachile lanata & \\
3. Ceratina gigantica & 10. Halictus sp. & 15. Megachile sp. & \\
4. Ceratina $\mathrm{sp.}$ & 11. Nomia himalayana & & \\
5. Anthophora $\mathrm{sp}$. & 12. Nomia elliotii & & \\
6. Amegilla $\mathrm{sp.}$ & & & \\
7. Thyreus $\mathrm{sp}$ - & & & \\
\hline
\end{tabular}

Table 2: Relative abundance of different solitary bees pollinators visiting Jatropha curcas bloom at Nahan. No. of bees/500 flowers $/ 10$ minutes

\begin{tabular}{|c|c|c|c|c|}
\hline Family & Genus/Species & Mean \pm S.E. & $\begin{array}{l}\text { Percentage } \\
\text { Population }\end{array}$ & $\begin{array}{c}\text { Family } \\
\text { Percentage }\end{array}$ \\
\hline \multirow{5}{*}{ Apidae } & Xylocopa fenestrate & $12.9 * \pm 2.3$ & 25.85 & \multirow{5}{*}{64.92} \\
\hline & Trigona iridipenis & $3.8 \pm 0.9$ & 7.61 & \\
\hline & Ceratina gigantic & $10.7 \pm 1.5$ & 21.44 & \\
\hline & Anthophora sp. & $2.6 \pm 0.7$ & 5.21 & \\
\hline & Amegilla sp. & $2.4 \pm 0.4$ & 4.80 & \\
\hline \multirow[b]{3}{*}{ Halictidae } & Halictus himalayensis & $4.8 \pm 0.8$ & 9.61 & \multirow[b]{3}{*}{20.64} \\
\hline & Halictus sp. & $2.1 \pm 0.9$ & 4.20 & \\
\hline & Nomia elliotii & $3.4 \pm 0.5$ & 6.81 & \\
\hline \multirow[b]{2}{*}{ Megachilidae } & Megachile flaviceps & $4.9 \pm 1.5$ & 9.81 & \multirow[b]{2}{*}{11.22} \\
\hline & Megachile sp. & $0.7 \pm 0.3$ & 1.40 & \\
\hline Andrenidae & Andrena sp. & $1.6 \pm 0.4$ & 3.20 & 3.20 \\
\hline
\end{tabular}

*Each value is an overall average for bee species

S.E. = Standard error about mean 


\section{International Journal of Science and Research (IJSR) \\ ISSN (Online): 2319-7064}

Index Copernicus Value (2013): 6.14 | Impact Factor (2015): 6.391

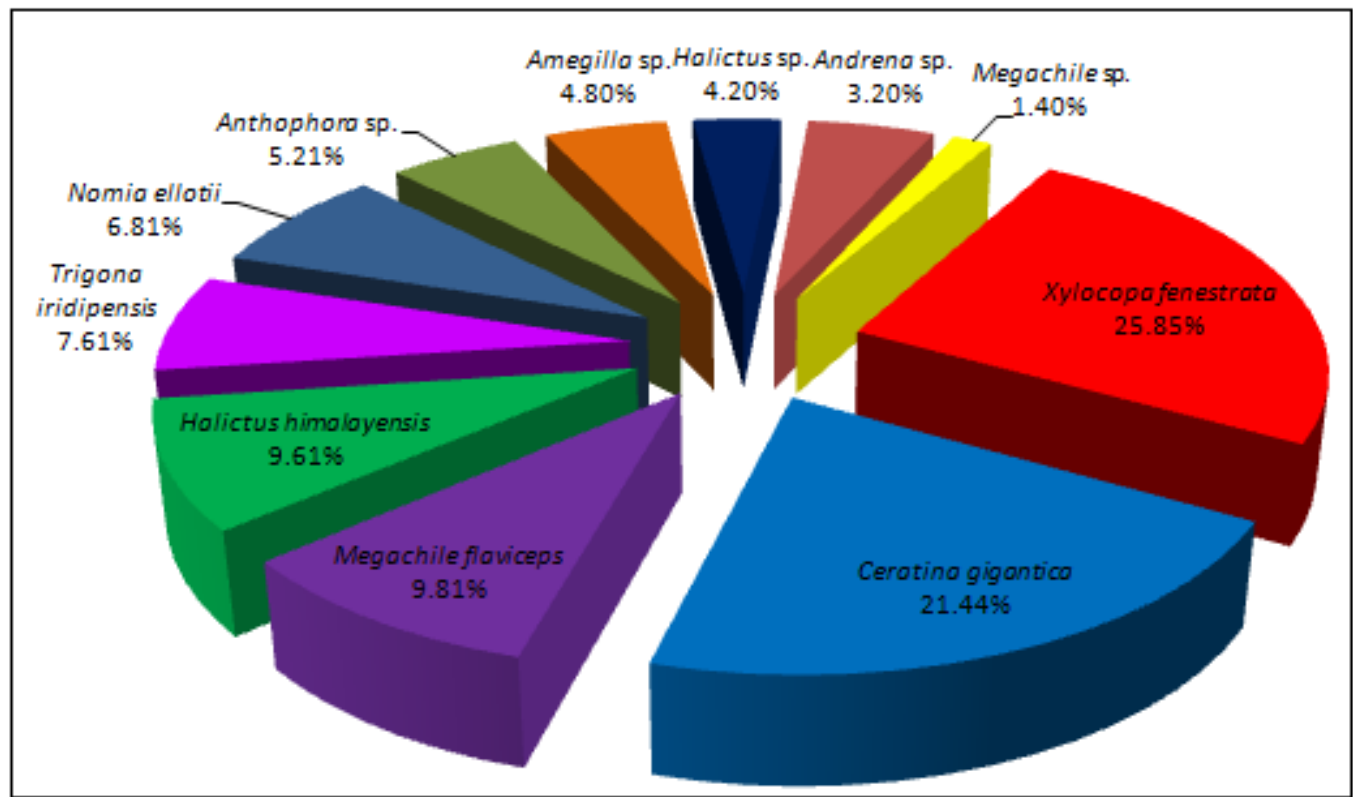

Figure 1: Relative abundance of different solitary bee pollinators visiting Jatropha curcas flowers at Nahan of Sirmour hills

Table 3: Relative abundance of different solitary bees pollinators visiting Jatropha curcas bloom at Arki. No. of bees/500 flowers 10 minutes

\begin{tabular}{|c|c|c|c|c|}
\hline Family & Genus/Species & Mean \pm S.E. & $\begin{array}{l}\text { Percentage } \\
\text { Population }\end{array}$ & $\begin{array}{c}\text { Family } \\
\text { Percentage }\end{array}$ \\
\hline \multirow{5}{*}{ Apidae } & Xylocopa fenestrate & $12.4 \pm 2.2$ & 24.84 & \multirow{5}{*}{63.32} \\
\hline & Trigona iridipenis & $3.5 \pm 0.8$ & 7.01 & \\
\hline & Ceratina gigantic & $10.5 \pm 1.6$ & 21.04 & \\
\hline & Anthophora sp. & $2.7 \pm 0.4$ & 5.41 & \\
\hline & Amegilla sp. & $2.5 \pm 0.6$ & 5.01 & \\
\hline \multirow{3}{*}{ Halictidae } & Halictus himalayensis & $4.6 \pm 1.6$ & 9.21 & \multirow[b]{3}{*}{20.44} \\
\hline & Halictus sp. & $1.8 \pm 0.7$ & 3.60 & \\
\hline & Nomia elliotii & $3.8 \pm 0.5$ & 7.61 & \\
\hline \multirow[t]{2}{*}{ Megachilidae } & Megachile flaviceps & $4.7 \pm 0.5$ & 9.41 & \multirow{2}{*}{11.02} \\
\hline & Megachile sp. & $0.8 \pm 0.3$ & 1.60 & \\
\hline Andrenidae & Andrena sp. & $2.6 \pm 0.7$ & 5.21 & 5.21 \\
\hline
\end{tabular}

*Each value is an overall average for bee species

S.E. $=$ Standard error about mean

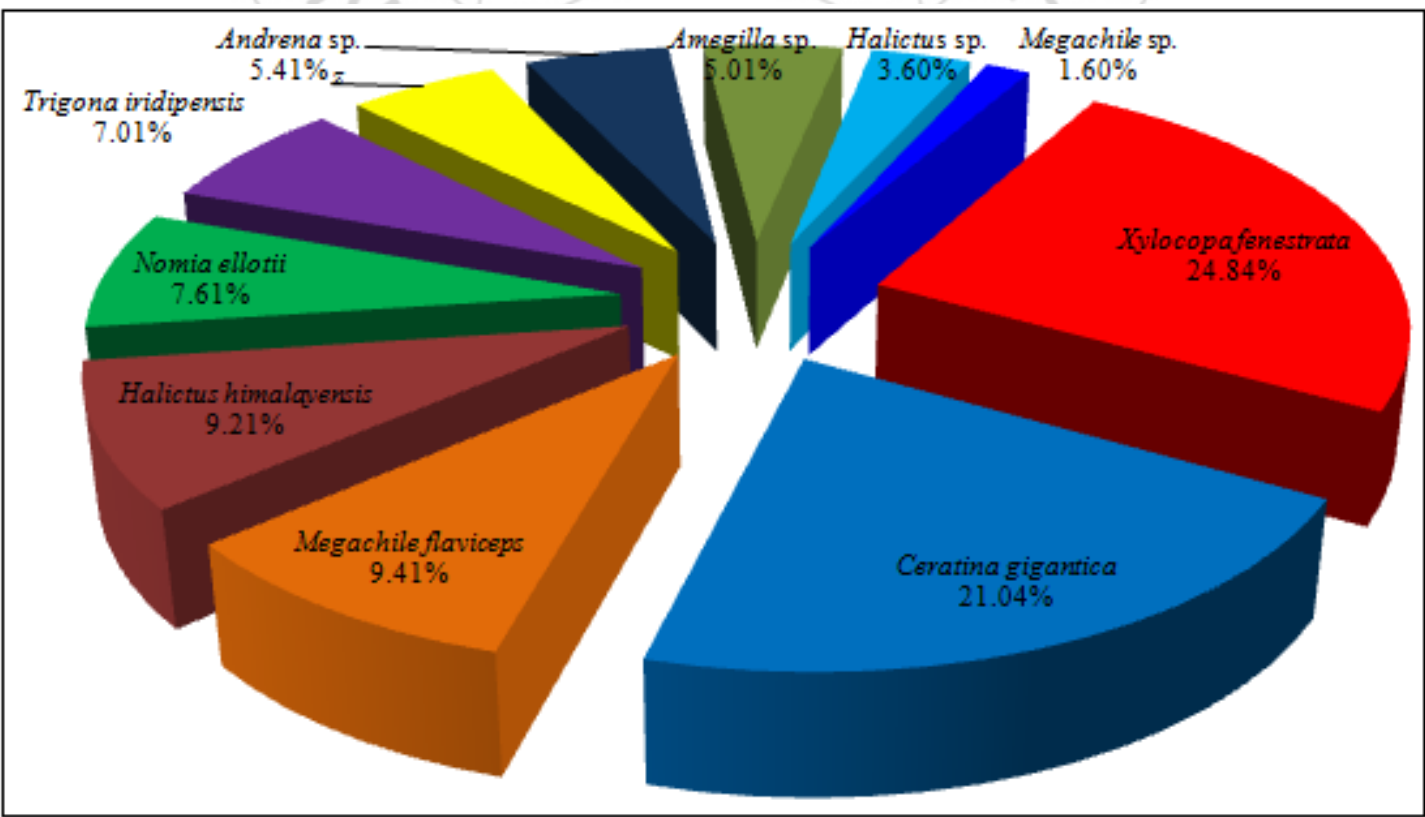

Figure 2: Relative abundance of different solitary bee pollinators visiting Jatropha curcas flowers at Arki of Solan hills.

\section{Acknowledgements}

Paper ID: NOV163813
The authors are thankful to the Chairperson, Department of Biosciences, Himachal Pradesh University, Shimla for

Volume 5 Issue 5, May 2016 www.ijsr.net 


\section{International Journal of Science and Research (IJSR) \\ ISSN (Online): 2319-7064 \\ Index Copernicus Value (2013): 6.14 | Impact Factor (2015): 6.391}

providing the necessary facilities and for encouragements Thanks are also due to the University Grant Commission (UGC), New Delhi for providing the financial assistance in the form of UGC-BSR (NET).

\section{References}

[1] Abrol, D.P. 1989. Studies on ecology and behaviour of insect pollinators frequenting strawberry blossoms and their impact on yield and fruit quality. Tropical Ecology 30: 96-100.

[2] Ashoke, B., Kalyani, D. and Subodh, K. D. 2005. Floral biology, floral resource constraints and pollination limitation in Jatropha curcas L. Pak. J. Biol. Sci. 8(3): 456-460.

[3] Atwal, A.S. 1970. Insect pollinators of crops. Punjab Agricultural University Press,Ludhiana. 116 p.

[4] Batra, S.W.T. 1977. Bees of India, their behaviour, management and a key to the genera. Oriental Insects 11 (3/4): 289-324.

[5] Burkill, I.H. 1909. Insects and flowers in India. In: Maxwell-Lefroy, H. and Howlett, F. M. (eds.), Indian insect life. Agriculture Research Institute, Pusa. Govt. of India Publication. 222-223pp.

[6] Free, J.B. 1993. Insect pollination of crops. Academic Press, London, 786 pp.

[7] Gary, N.E. 1992. Activities and behaviour of honeybees. In: The hive and honeybee (eds.: Dadant and sons). Dadant and sons, Hamilton, Illinois, USA.

[8] Goodman, L.J. and Fisher, R.C. 1991. The behaviour and physiology of bee. CAB International Walling Ford, U.K.

[9] Gupta, R.K. 1987. On a new subgenus Orientoheriades and two new species of genus Heriades Spinola from India. Reichenbachia 25(15): 67-71.

[10] Gupta, R.K. 2003a. (The diversity of bees (Hymenoptera: Apoidea) in India. In: Gupta, R. K. (ed.), Advancements in insect biodiversity. AgroBios (India). 53-78pp.

[11] Kapil, R.P. 1986. Pollination Biology-An Analysis. Inter-India publ., New Delhi, 1-300.

[12] Katembo, B. I. and Gray , P. S. 2007. Africa, seed and biofuel. J. MultiDiscipl. Res. 1:1-6.

[13] Kevan, P.G. 2003. Pollination for the 21st century: integrating pollinator and plant inter dependence. In: K. Strickler and J.H. Cane [eds] For Nonnative Crops, Whence Pollinators of the Future. Thomas Say Publication of the Entomological Society of America, Lanham.

[14] Khan, M. R. and Khan, M. R. 2004. The role of honey bees Apis mellifera L. (Hymenoptera: Apidae) in pollination of apple. Pak. J. Biol. Sci 7: 359-362.

[15] Maes, W. H., Trabucco, A., Achten, W. M. J. and Muys, B. 2009. Climatic growingconditions of Jatropha curcas L. Biomass Bioenerg. 33:1481-1485.

[16] Mattu, V.K. 2008. Conservation of bee pollinators for crop pollination. Proc. $2^{\text {nd }}$ Int. Bee. Cong. Bhutan.

[17] Mattu, V.K. 2010. Implication of climate change on the pollinator: Some issues and challenges. Proc. Nat. Sym. Persp. Challng. Integ. Pest Manag. Sustain. Agric. Solan, 122-123.
[18] Mavromoustakis, G.A. 1938. Some new Asiatic bees of subfamily Anthidiinae. Annals and Magazine of Natural History (10) 9: 151-157.

[19] Mavromoustakis, G.A. 1951. Further contributions to our knowledge of the Ethiopian Anthidiinae (Hymenoptera: Apoidea) and their classification. Annals and Magazine of Natural History (12) 4: 962-981.

[20] McGregor, S.F. 1976. Insect pollination of cultivated crop plants. U.S. Dept. Agric. Handbook, 411 pp.

[21] Michener, C.D. 1966. A new species of Anthocopa fron India (Hymenoptera: Megachilidae). Entomologist 99: 146-150.

[22] Michener, C.D. 1974. The social behaviour of the beesA comparative study. Harvard University Press, Cambridge, Massachusetts. XII+404 pp.

[23] Michener, C.D. 1994. Native bees in seventeenth centuary Latin America. Melissa 8: 9.

[24] Micnener, C.D. 2000. The bees of the world. The John Hopkins University Press, Baltimore and London, XIV+1-913 pp.

[25] Mishra, R.C., Dogra, G.S. and Gupta, P.R. 1976. Some observations on insect pollinators of apple. Indian Bee J.38: 20-22.

[26] Morse, R.A. and Calderone, N.W. 2000. The value of Honeybees as Pollinators of US Crops in 2000 (http://bee.airoot.com/beeculture/pollinatio 2000).

[27] Muthuraman, M. and Saravanan, P. A. 2004. Utilization of stingless bees for crop pollination. Indian Bee $\mathrm{J}$. 66:(1-2): 58-64.

[28] Peters, D.S. 1972. Drei neue Arten der Megachilidae aus Mexico. Senckenbergiana Biologica 53: 373-382.

[29] Popov, V.B. 1936. A new bee of the genus Ctenoplectra Sm. Proceedings of the Royal Entomological Society of London (B) 5: 78-80.

[30] Raju, A.J.S. and Ezradanam, V. 2002. Pollination ecology and fruiting behavior in a monoecious species, Jatropha curcas L.(Euphorbiaceae). Current Science 83: 1395- 1398.

[31] Sharma, J.R. and Mudgal, V. 1997. Floristic Diversity and Conservation Strategies in India. In: Botanical survey in India (eds.: V. Mudgal and P.K. Hajra). Ministry of Environment and Forests, 5.

[32] Verma, L.R. and Chauhan, P. 1985. Distribution, abundance and diversity of insect pollinators in apple orchards of Shimla hills. Indian J. Ecol. 12: 286-292. 